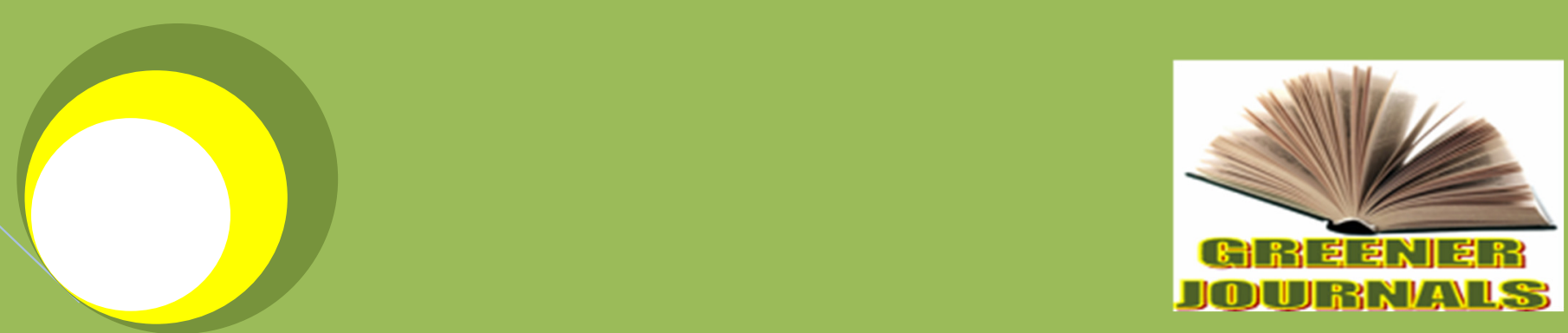

Greener.Journal of Social Sciences ISSN: 2276-7800 ICV: 5.99

Coping Strategies of the Early Aku Settlers in Torkisong (Esu) to

Danpullo Encroachment in the Late 1990s: A Historical and

Sociological Overview

By

John Uka 
Review Article (DOI: http://doi.org/10.15580/GJSS.2016.4.101916182)

\title{
Coping Strategies of the Early Aku Settlers in Torkisong (Esu) to Danpullo Encroachment in the Late 1990s: A Historical and Sociological Overview
}

\author{
John Uka \\ Former research student, College of Health and Social Care, School of Social and Political Sciences, University of \\ Lincoln, (UK) \\ Email: mihukason @yahoo.com
}

\begin{abstract}
The arrival and settlement of Aljaji Baba Amadou Danpullo at lbe Wundele, in Esu, Mecnhum Division in 1987 precipitated further land sales which extended Danpullo's parameters to Torkisong; one of the areas not included in the 1987 deal. This drew criticism from the early Aku settlers (simply called settlers within this study) and farmers of Torkisong because the operationalising strategy was undefined. A strengths perspective is adopted for this study which examines the settlers' coping strategies in the conflicts. This historical overview is written from empirical observation and draws upon coping theories to make a case for the settlers' coping prowess until 2004 when relocation appeared the best option.
\end{abstract}

Key Words: Settlers, encroachment, coping, Torkisong, Esu, Danpullo.

\section{RESEARCH CONTEXT}

Torkisong is a farming estate in Esu village in Fungom Sub-Division in Menchum Division of the North West region of Cameroon. Esu is predominantly agro-pastoral (Fang, 2013). Pastoralism is undertaken chiefly by the Akus who tend to settle in the valleys of neighbouring and far off bushes like Mulang, Sangwa and Torkisong among others. Torkisong has thick forests fondly called "black bush" and vast grazing land. Prior to Danpullo's arrival in Torkisong, the cattle herds in Torkisong traditionally belonged to four families; Mallam Tashi, Hassan Gonda, Maoku (whose real name is Djibrila Nakalua) and Manga (Laoluk) Albakar who have been given the acronym MAHAMAMA within this study. A greater portion of the cattle belonged to Mallam Tashi who had more independent adult male children at the time of the encroachment. The ancestral origin of these families is Kano in Nigeria as depicted by the nineteenth century migration trajectories which produced a hybrid of ethnic identities (Dognin 1981, cited in M. Peliccan, 2008). The Akus came to the Bamenda grasslands (where Esu falls) predominantly from the Jos plateau in Nigeria "from the 1940s because of favourable grazing conditions and administrative policies and they have settled on the lowland pastures on the northern fringes of the Bamenda Highlands" (Pelican, 2008:542). They have integrated and engaged well with their communities. MAHAMAMA had cattle in the hinterlands under the stewardship of "ganako", local parlance for herders. The cattle owners' locally called "patrons" visited the herders weekly to assess the progress of the herds. The arrival of the wealthy, business magnet, Alhaji Baba Amadou Danpullo, curbed grazing and farmland and displaced MAHAMAMA progressively forcing their stationed cattle to retreat towards far off thick and hitherto dreaded bushes which harbour ticks and wild animals like tigers which are a threat to the survival of the cattle.

\section{LITERATURE REVIEW}

Despite extensive studies on Farmer-grazier conflicts in Menchum Division (Ngwoh, 2006, Kah, 2009; Angwafo, 2014; Manu et al, 2014), there is a paucity of studies on how the Akus displaced by Danpullo fared or are faring in the aftermath of the conflicts. Often, the problem has been approached from the perspective of causal factors. For instances, Kah (2009:190) argues that farmer-grazier conflicts in Wum are triggered by "land degradation and scarcity". This was not the case in Torkisong where Danpullo overlooked the abundance of land and adopted attacking and callous tactics by "seeking out" or harassing the settlers and the farmers through stationing cattle by 
their compounds and rampantly destroying their crops. This move aligns Ferks et al (2014) argument that land conflicts are more complicated than thought and therefore positioned squarely within Bavinck et al (2014:2, cited in P.T. Angwafo, 2014) continuum of mild tension to outright violence (Angwafo, 2014). This displacement tactics were executed by stationing herdsmen and cattle at strategic positions and very close to the settlers' compounds with intent of making life uncomfortable for the latter. After several years of strained coexistence, the general uncomfortableness became challenging and unbearable. Stories of widespread invasion of privacy, insecurity, looting and the destruction of property perpetrated against the settlers, led to misgivings. There was almost no demarcation between the settlers' personal space and Danpullo herdsmen. In response, the settlers resorted to adaptive solutions to safeguard themselves by leaving Torkisong and supervising the development of their herds from outside Torkisong. This process, which understandably began at the same time for almost all the families, was attained at different times for different reasons. Hassan Gonda and Maoku found Danpullo's presence unbearable and decided to leave Torkisong. The exact reasons for their quick capitulation to the hardline tactics of Danpullo are unknown but it could be argued that Danpullo's activities elsewhere in the North West region contributed or informed their decisions. Upon leaving Torkisong, Hassan Gonda acquired land adjacent the settlement camp of the victims of the Lake Nyos disaster of August $21^{\text {st }} 1986$ where he settled himself and his independent adult male children (Halidou, Musa, Sulle etc); most of whom became involved in local transport business called "benskin" as the primary source of livelihood. Maoku settled within four kilometres from Government High School Esu. Both Hassan Gonda and Maoku left their cattle in Torkisong. Informal interviews with Maoku showed that his family is more comfortable at his present site than at "post-Danpullo" Torkisong. Hassan Gonda's children found life in Esu central more meaningful and they applied themselves towards various economic activities to supplement their income.

\section{Theorising the Encroachment}

Research highlights the importance of theory in making sense of situations or events (Oko, 2008; Uggerhoi, 2012). Kubler-Ross (1969) five stage grief model encompassing denial, anger, bargaining, depression and acceptance is instructive of the settlers' coping mechanisms. These stages are unique and may be experienced differently by individuals. According to Kubler-Ross (1969), grief commences with the feelings of denial and isolation that are a temporary reaction to the grieving individual's state of shock. During this phase, MAHAMAMA was in denial that Danpullo was invading and gaining control of most of their occupied land despite the visible and rapid influx of Danpullo's cattle; usually marked by ear rings. MAHAMAMA could not come to terms with the fact that their loyalty to custodians of Esu was overlooked. Even when Hassan Gonda and Maoku left Torkisong, Mallam Tashi alongside his adult children and Manga Albakar were still in denial feeling that their solidarity would overpower Danpullo's usurping efforts. This denial was closely followed by anger vented towards Danpullo over the general encroachment bottleneck and for stationing cattle around their compounds despite the abundance of land in Torkisong. Kubler-Ross postulates that individuals at the anger stage begin recognizing their misfortune, evoking feelings of anger (KublerRoss 1969); which can be vented at others or at the self in the form of guilt and blame in not approaching the problem differently (Kubler-Ross \& Kessler 2005). Unable to stop Danpullo's thick-skinned and outrageous land grapping tactics or ploys, MAHAMAMA's anger led to bargaining, which is an attempt by the mourning individual to postpone loss (Kubler-Ross 1969). MAHAMAMA's bargaining was marked by some reconciliatory attempts with Danpullo's herders and supervisors through negotiating pasturing boundaries and forging good relationships. These attempts proved abortive and the encroachment quickly moved from pilfering to plundering in near "scorched earth" fashion especially around the settlers' compounds where herds of cattle were "pushed" from the main base at Wundele and outside Esu to occupy the identified spots. This stage was delicate and decisive producing diverse outcomes. While Hassan Gonda and Maoko surrendered and accepted their fate with minimal resistance, Manga Albakar and Mallam Tashi refused to throw in the towel without a fight. This was quite understandable for these two families for various reasons. Besides the exigencies of leaving the familiar abode, acquiring land near Esu was difficult and expensive, let alone for at least five or six people for Tashi and three for Manga Albakar. Unable to handle this pressure, the settlers went into depression, which is marked by a sense of great loss of self-esteem, a sense of futility and despair (Messing et al, 2015). This was accompanied by a gradual acceptance that they have been made "strangers" in a land that used to be theirs. Hassan Gonda and Maoku attained this stage quicker than Mallam Tashi and Manga Albakar. This acceptance reinvigorated the settlers' control over their lives (Messing et al, 2015) by way of making informed decisions.

This process was daunting and emotionally draining for MAHAMAMA with a huge sense of grief. According to Fahlery (1991:141), grief is "the process through which one passes in order to recover from a loss" (Currer, 2007:16). This process highlighted MAHAMAMA's coping strategies. The dual-process model of loss and restoration (Stroebe and Schut, 1999) is instructive within this study. While loss focuses on separation and distress, restoration focuses on developing ways in which to continue the practical aspects of living on one's own. The corpus of this study is on the latter. According to Currier (2007:15), loss denotes the absence of someone or something and is "the 
disadvantageous or detrimental aspects of a change". Concurring this, Hooyman and Kramer (2006:2) argue that "loss always result in the deprivation of some kind; in essence, we no longer have someone or something that we used to have". MAHAMAMA was unhappy to lose control over vast portions of land which was traditionally theirs and this loss was significant in their lives in the sense that it led to their resettlement which has subsequently become part of their lives. Their children and grandchildren who were born and bred in Torkisong witnessed a seismic shift in their lives; they had to shift attention from traditional cattle rearing to a more sedentary or "near settled" life with limited land; contrary to the situation in Torkisong.

It is worth pointing out that as MAHAMAMA grieved over the significant loss of "being made strangers" in land traditionally perceived as theirs, they gave the grief a good shot or fight. With the crux of this study being to examine the strategies MAHAMAMA adopted towards the Danpullo's onslaught, this study therefore departs from the deficit approach, most studies adopt, of focusing on the impact of the crisis on the victims and examines the strengths or coping strategies displayed by the settlers.

\section{Coping strategies}

Dealing with displacement can be overwhelming. Coping is a term that thrust itself in the skills that are salient to maintain the equilibrium between sudden changes in life patterns and daily live (Watkins, 2009). Coping and stress management are crucial in responding to adversities. Coping strategies can either be practical or psychological (Leppanen, 2008). According to Leppanen (2008:1197) "problem-focused coping mechanisms are geared towards eradicating or supervising the stressor and "emotion-focused" are geared towards supervising emotional responses to the stressor" (Uka, 2012). Therefore, understanding ongoing struggles is vital in appreciating coping prowess and resilience. Resilience denotes "both the effective coping and adaptation in spite of adversity" (Zander et al (2010:97) and is relevant here because it portrays individual coping under the same tragedy (Currer, 2007). The settlers' coping strengths were principally twofold; changing the internal status quo and maintaining the external status quo.

Maintaining the external status quo was the first strategy which intensified after securing the internal status quo. This entailed maintaining the cattle at current spots (especially in the black bush) with more supervision, urgency for permanence and forging relationships with Danpullo herders and supervisors. The primary response was exhibited by clinging unto the hills where their cattle were stationed with perceived exclusivity. This was accompanied by intensive drilling of the cattle to spend the night around the hut and consequently avoid problems with Danpullo herders and or supervisors. To ensure that the herds were properly cared for, the patrons visited the herdsmen weekly bringing money and basic items occasionally as well as ensuring that the herdsmen overnight stays away from the hut are authorised. It could be argued that Danpullo's arrival was a mixed blessing; it led to better or intensive land management in the black bush among the settlers thus offsetting Danpullo's extensive land use and thereby bringing about a change or transition in the normal ways of life. Danpullo encroached Torkisong between 1993 and 1995 but his influence was felt by the settlers from 1996 when the brute tactics commenced. As stated earlier, the settlers' responded to this brute force by intensifying the spirit of solidarity among them; becoming each other's keeper and encouraging their herders to act in like fashion. Moreover, the relationship between these families; strengthened either by marriage or birth, made visits to the black bush to be mutually arranged and the construction of huts close to each other where topography permit became a common practice. This aligns Herbert Spencer's postulation that "it is not the strongest of species that survives, but the one most responsive to change" (webpage). The settlers appeared to adapt well to this encroachment and have been able to work their way through in a bush now predominantly occupied by Danpullo's cattle. For example, Maoku has been able to maintain his cattle on the piece of land which use to be his compound and Yamusa and others have also been able to bring their cattle back to some of their abandoned spots. Also, stories of making special grazing arrangements with Danpullo supervisors surfaced. Though the full details or validity of these alleged arrangements or claims are unclear, nonetheless, these arrangements showcased the settlers' resilience in relinquishing control of portions of land in Torkisong. For the main therefore, the settlers were able to find a solution to Danpullo's encroachment and have become more tactful in dealing with Danpullo herders and supervisors over the years. The fact that they have continued to graze their cattle in Torkisong is a testament of their tactfulness and pliability.

Though Danpullo has systematically affected the lives of many akus in the division since his arrival in Esu in 1987, the akus have traditionally tended to move further bushwards but MAHAMAMA's case was unique in the sense that they moved both ways; bushwards as they seek exclusive controls on particular hills where their cattle was stationed and "townwards" as they seek to safeguard their families. Their resilience or brilliance has inspired many akus who have come to realise that it was foolhardy to be anti-Danpullo when Danpullo has come to stay in the village. As a result, most akus who would not otherwise work for Danpullo, have been able to pick up employment with Danpullo as a source of livelihood or to supplement their meagre amount of cattle.

Changing the internal Status quo was the second coping strategy and was adopted almost as a last resort. Hassan and Maoku's movements were less urgent compared to Tashi and Manga. As this wind of change and 
transformation blew across Torkisong, it had costly effects (such as loss) on the settlers. According to Currier, change involves difference, movement and alteration from the previous state to a subsequent one" (Currier, 2007:14). Safeguarding themselves and their families entailed securing land proximal to Esu central with as little as one or half a herd of cattle to provide milk for daily family upkeep. While Mallam Tashi acquired land at Kesaisai, his adult children like Yamusa, Hamidou, llyassu, Idrisa amongst others, acquired land very close to Esu at Ukaiwom. Subsequent displacement of Hamidou Tashi failed to move him further away from Esu. On the other hand, Manga Albakar, who has been the most resilient, sustained the encroachment by resettling his family on a very steep hill less than two kilometres from his traditional home while some of his adult children relocated to a different bush in Esu called Kejung alongside Manga's elder brother Nyailly Albakar.

In relocating, the settlers took their sheep along because the sheep required intensive surveillance. The sheep have been fenced to prevent the destruction of crops in nearby farms in Esu and straying which could lead to theft. Containing the sheep that traditionally "strayed" the hills in Torkisong demonstrates the settlers' resilience to adversity. Although safeguarding their families appeared to be the main relocation reason; it could be argued that this was also informed by Danpullo's activities elsewhere in the North West region like in Kom. According to one Cameroon newspaper, Le Messager, villages like Jinkfuin, Njinikijem, Baingo and Djichami in Belo Sub division in the North West region have been poorly treated by Danpullo where arrest and torture of local inhabitants have often proceeded allegations of "cow missing" albeit this is sometimes Danpullo's ploys to intimidate and acquire more land (Le Messager, August 12 ${ }^{\text {th }}$ 1993: 6 cited in S.S. Nana, 2003). The settlers' relocation minimised conflicts with Danpullo and gave the latter much control over the national land in Torkisong from where he connects with his other hegemonies like Sangwa as well as gave the settlers time to reflect and approach the problem in a more flexible and tactful way. This has been largely successful because the settlers have maintained their cattle in the black bush and have been able to bring some cattle back to their former compounds under ganako stewardship after alleged negotiations and or good relationships with Danpullo supervisors.

\section{CONCLUSION}

These coping strategies showcased the tactfulness, resilience and unrelenting efforts of the settlers. Perhaps if they had engaged in outright battle with Danpullo, Danpullo would have adopted more cruel tactics towards the settlers and the seemed "after the fact" coexistence would not have been established. This again highlights the importance of diplomacy or negotiations in conflicts management. Though the conflict over grazing land in Esu is ongoing with devastating and deplorable outcomes since 2013 (such as arrest, insecurity, destruction of property, imprisonment and threats of imprisonment of indigenes and other malpractices), the settlers' response demonstrated that it would be folly to get angry with Danpullo and his tactics and then abandon Torkisong all to Danpullo. They [the settlers], after due reflection seem to realise the need for compromise and self-awareness. As such, special arrangements are commonplace. These coping strategies also validate the fact that displacement or crisis is a mixed blessing; it can lead to services and hardship. Besides exposing MAHAMAMA to services like education (primary and secondary) and local transport trade, the relocation led to better land management as well as their full integration into the Esu community. When Yamusa, Hamidou, llyasu and Idrisa settled at Ukaiwom, it led to the creation of Government Primary School Ukaiwom in 2012 and the school went operational in the same year with Valentine Kum Kai as its pioneer headmaster. The school, which pulled many pupils from nearby bushes and compounds, scored a hundred percent in turning out its first badge at the First School Leaving Certificate exam in 2013. Moreover, the settlers have become more industrious and efficient in their land management skills as they cultivate crops on alternate pieces of land which was not the case when they were in Torkisong. This has also been done by allowing Esu natives to farm around their compounds or land to prepare good pasture for their cattle after harvest. Furthermore, because most of the settlers feel they are now full-fledged members of the community, they have become more resilient to displacement. For instance, when Hamidou Tashi was further displaced from where he settled when he left Torkisong, he was able to negotiate for alternative land and re-establish himself in a nearby bush within a short time. These adaptive skills might have remained untapped if the "Fardorre" hegemony had not been dismantled by Danpullo. Fardorre is a famous stone in Torkisong which is often used to describe Torkisong. It is famous because it can be seen from Esu central and is believed to be home of some gods in Torkisong. Further studies are required on not only the settlers but also the displaced farmers to understand their lived experiences. Unfortunately most of the early non-akus or non-pastoral farmers affected by the encroachment like Pedro Chiy, Sabi Kedzi, Goodboy Zih, Solomon Ukah amongst others are dead; they died without any debrief or compensation plan from Danpullo. 


\section{REFERENCES}

Angwafo, P.T. (2014). Contesting Land and Identity: the case of Women Cultivators and Fulani Herders in Wum, Northwest region Cameroon. M.A Thesis submitted to the University of Leiden: The Netherlands.

Currer, C (2007) Loss and Social Work. Exeter: Learning Matters.

Fang, A. Z (2013). Environmental Changes and their Implications for Agro-pastoral Activities in Menchum Division in the North West Region of Cameroon, Masters Thesis Submitted to the University of Buea (unpublished).

Hooyman, N and Kramer, B (2006). Living through Loss: Interventions across the lifespan. New York: Colombia University Press.

Kah., H.K (2013) Gender and Livestock Farming in Laimbweland, Cameroon, 1980s-2011. Journal of Sustainable Development in Africa 15 (1): 1520-5509.

Kah.H. (2009), 'Governance and land conflict: the case of Aghem-Wum 1966-2005' in Fonchingong.T.S \& Gemandze .J.B [eds] Cameroon: the stakes and challenges of governance and development, Langaa, CIG Mankon-Bamenda

Kubler-Ross, E (1969). On death and Dying. London: Tavistock

Kubler-Ross, E. \& Kessler, D. (2005) On Grief and Grieving: Finding the Meaning of Grief through Five Stages of Loss. Scribner, New York, NY.

Manu, I N; Andu., W.N, Tarla, D.N and Agharih, W.N (2014). Causes of Cattle theft in the North West Region of Cameroon, Scholarly Journal of Agricultural Science 4(4): 181-187.

Messing, J.T, Mohr, R. and Durfee, A. (2015). Intimate Partner violence and Women's experiences of grief. Child \& Family Social Work 20 (1): 30-39.

Nana, S.S (2003). Why we refused to align ourselves to reactionary forces against our community available at http://www.justice-dignity.net/wp-content/themes/greenstimulus/press_review/Mutations_rejoinder_Sept_2003.pdf. Accessed 4/5/2015.

Ngwoh, V.K (2006) "Farmer-Grazier Conflicts in Menchum Division 1943-2005: A Study of Contested Hegemony over Land". M.A Dissertation in History submitted to the University of Buea, Cameroon.

Oko, J. (2008). Understanding and Using Theory in Social Work. Exeter: Learning Matters

Pelican, M. (2008). Mbororo Claims to Regional citizenship and minority status in NorthWest Cameroon. Africa 78 (4).

Stroebe, M., \& Schut, H. (1999). The dual process model of coping with bereavement: Rationale and description. Death Studies 23(3), 197-224. Vázquez Bandín, C. (2012). The process of grief according to Gestalt therapy. Gestalt Review 16(2), 126-144.

Uka, J. (2012) "Coping Strategies of Carers of People with Mental Health Problems", MSc. Dissertation submitted to the University of Lincoln, UK (unpublished).

Uggerhoj, L. (2012). Theorising Practice research in Social Work In Edgar Marthinsen and Ilse Julkunen (eds) (2012). Practice Research in Nordic Social Work: Knowledge production in transition. London: Whiting \& Birch Limited.

Watkins, C., 2009. Easier said than done: Collaborative Learning. School Leadership Today, 10 May, pp. 22-25 Wood, D., Bruner, J. \& Ross, G., 1976. The role of tutoring in problem solving. Journal of Child Psychology and Psychiatry, Volume 17, pp. 89-100.

Zander, M, Hutton, A. and King, L (2010) Coping and Resilience Factors in Paediatric Oncology Nurses, Journal of Paediatric Oncology Nursing, 27(2) 94-1

Cite this Article: Uka J (2016). Coping Strategies of the Early Aku Settlers in Torkisong (Esu) to Danpullo Encroachment in the Late 1990s: A Historical and Sociological Overview. Greener Journal of Social Sciences, 6(4): 075-079, http://doi.org/10.15580/GJSS.2016.4.101916182 